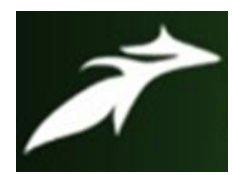

Pilli Rosey Chetana et al, International Journal of Advances in Agricultural Science and Technology,

Vol.7 Issue.12, December-2020, pg. 45-49

ISSN: 2348-1358

Impact Factor: 6.057

NAAS Rating: 3.77

\title{
A Study on Knowledge of Beneficiaries about MGNREGA in Bapatla Mandal of Guntur District, Andhra Pradesh
}

\author{
Pilli Rosey Chetana; Dr. Jahanara \\ Author, M.Sc. Agricultural Extension and Communication \\ Professor and Head, Dept. of Agricultural Extension and Communication, SHUATS, Prayagraj-211007. \\ DOI: 10.47856/ijaast.2020.v07i12.007
}

\begin{abstract}
The basic objective of this research is to study beneficiaries' knowledge about MGNREGA in Bapatla Mandal of Guntur district, Andhra Pradesh. MGNREGA aims to provide a steady source of income and livelihood security for the poo, vulnerable and marginalized. As the scheme assures 100 days guaranteed employment to the rural por in order raise their standard of living and empower them economically, it has been receiving variegated responses from different parts of the country. So, it felt necessary to study about the knowledge of beneficiary respondents about MGNREGA. In this regard, a primary field study has been conducted with 60 job card holders of MGNREGA regarding their insight on the programme whether it raised their standard of living and brought any changes in their financial aspects or not. This paper mainly focusses on some of the basic awareness issues such as job card, work man days, muster roll, wage rate, social audit, shelf of works undertaken etc.

Keywords: MGNREGA, Job Cardholder, Beneficiaries, wages, work man days, Social Audit, Muster roll.
\end{abstract}

\section{INTRODUCTION}

Rural India has seen many changes since independence. Rural development has been a crucial issue for states with large number of rural population as various programmes were launched for the development of the poor and marginal people living in rural areas. Role of rural areas in development of the country like India needs no proof as it is evident from the orientation of government policies that rural areas are acting as drive engines for the growth of the country. The government in the recent past has framed numerous schemes and programmes for the development of rural areas of the country in order to tap the resources for the betterment of rural masses. The introduction of wage programmes like MGNREGA in the area have helped to provide thrust to development process and can therefore be termed as boon for the people due to its demand-oriented approach which makes the authorities responsible as well as accountable for providing employment to individuals. Times of India in its report in the year 2013 considered MGNREGA as a boon in rural landscape and said that it became a fact of life in rural India.

National Rural Employment Guarantee Act 2005, later renamed as Mahatma Gandhi National Rural Employment Guarantee Act (MGNREGA), is an Indian Labour Law and social security measure that aims to guarantee the 'right to work'. MGNREGA, a centrally sponsored wage employment scheme, aims at providing livelihood security to the rural poor. MGNREGA is a social safety net and the performance of the scheme is highly appreciable in regard of public works (Das,2016). MGNREGA is considered as a 'Silver Bullet' which was implemented in the year 2006 with a main 


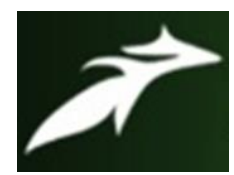

Pilli Rosey Chetana et al, International Journal of Advances in Agricultural Science and Technology,

Vol.7 Issue.12, December-2020, pg. 45-49

ISSN: 2348-1358

Impact Factor: 6.057

NAAS Rating: 3.77

objective to eradicate poverty by providing 100 days of work per year to all those households whose adults are ready to do unskilled physical labour at the minimum wage. This statute is hailed by the Government as "the largest and most ambitious social security and public work programme in the world". The World Development (2014) in its report termed it a "stellar example of rural development". The works undertaken in MGNREGA had helped to improve agricultural production besides rural sanitation improvement (Diwakara, 2017).

In the context of Andhra Pradesh, MGNREGA was implemented on February $2^{\text {nd }}, 2006$ from Anantapur town.

\section{OBJECTIVES OF THE STUDY}

The main objectives of the study are:

1. To study the socio-economic profile of the beneficiaries in Bapatla Mandal.

2. To know about the Beneficiaries' Knowledge about MGNREGA.

\section{RESEARCH METHODOLOGY}

The study is based on both primary and secondary data. The Primary data is collected with the help of pre-tested structured interview schedule designed especially in the light of objectives setup for the study.

The secondary data will be collected from Library, journals, books papers and documents related to the topic of the research. The collected data are analyzed and interpreted with the help of simple percentage method.

For the present micro study, out of total 120 respondents, 60 beneficiaries have been selected with the help of simple random sampling.

\section{RESULTS AND DISCUSSIONS}

Table 1 Distribution of respondents based on their Socio-Economic profile

\begin{tabular}{|l|l|l|l|}
\hline S. No & Independent Variables & Frequency & Percentage (\%) \\
\hline 1. & Age & 19 & \\
& 20-35 years & 22 & 31.66 \\
& 36-50 years & 19 & 36.68 \\
& 50 years and above & & 31.66 \\
\hline 2. & Gender & 25 & \\
& Male & 35 & 41.67 \\
& Female & 58.33 \\
\hline
\end{tabular}




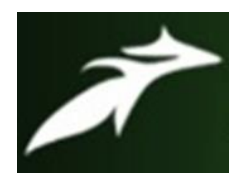

Pilli Rosey Chetana et al, International Journal of Advances in Agricultural Science and Technology,

Vol.7 Issue.12, December-2020, pg. 45-49

ISSN: 2348-1358

Impact Factor: 6.057

NAAS Rating: 3.77

\begin{tabular}{|c|c|c|c|}
\hline 3. & $\begin{array}{l}\text { Education } \\
\text { Illiterate } \\
\text { Primary } \\
\text { Secondary } \\
\text { High School } \\
\text { Intermediate } \\
\text { Graduation }\end{array}$ & $\begin{array}{l}17 \\
40 \\
3 \\
0 \\
0 \\
0\end{array}$ & $\begin{array}{l}28.33 \\
66.67 \\
5 \\
0 \\
0 \\
0\end{array}$ \\
\hline 4. & $\begin{array}{l}\text { Caste } \\
\text { General } \\
\text { BC } \\
\text { SC } \\
\text { ST }\end{array}$ & $\begin{array}{l}7 \\
9 \\
44 \\
0\end{array}$ & $\begin{array}{l}11.67 \\
15 \\
73.33 \\
0\end{array}$ \\
\hline 5. & $\begin{array}{l}\text { Occupation } \\
\text { Farmer } \\
\text { Agricultural Laborer } \\
\text { Others }\end{array}$ & $\begin{array}{l}10 \\
41 \\
9\end{array}$ & $\begin{array}{l}16.67 \\
68.33 \\
15\end{array}$ \\
\hline 6. & $\begin{array}{l}\text { Type of family } \\
\text { Nuclear } \\
\text { Joint }\end{array}$ & $\begin{array}{l}27 \\
33\end{array}$ & $\begin{array}{l}45 \\
55\end{array}$ \\
\hline 7. & $\begin{array}{l}\text { Type of House } \\
\text { Hut/Kaccha } \\
\text { Semi-Cemented } \\
\text { Cemented }\end{array}$ & $\begin{array}{l}0 \\
8 \\
52\end{array}$ & $\begin{array}{l}0 \\
13.33 \\
86.67\end{array}$ \\
\hline 8. & $\begin{array}{l}\text { Size of Land Holding } \\
\text { Landless } \\
\text { Upto } 3 \text { acres } \\
4-6 \text { acres }\end{array}$ & $\begin{array}{l}50 \\
8 \\
2\end{array}$ & $\begin{array}{l}83.34 \\
13.33 \\
3.33\end{array}$ \\
\hline 9. & $\begin{array}{l}\text { Annual Income } \\
\text { Upto } 20,000 \\
\text { Upto } 30,000 \\
\text { Upto } 40,000 \& \text { above }\end{array}$ & $\begin{array}{l}50 \\
8 \\
2\end{array}$ & $\begin{array}{l}83.34 \\
13.33 \\
3.3\end{array}$ \\
\hline
\end{tabular}

From the above Table 1, it is evident that majority of the beneficiaries belonged to middle age group (36-50 years) and 31.66 per cent fell equally in both old age and young age category. 58.33 per cent of the beneficiaries were female were as 41.67 per cent were male. In Education, 66.6 per cent of the beneficiaries were educated upto primary school education whereas 28.33 percent were completely illiterates. 5 per cent of the beneficiaries were educated upto upper primary school. On the basis of the Caste, 73.33 per cent of the beneficiaries belonged to SC category, 15 per cent belong to BC category and 11.67 per cent belong to general category. Majority ( 85 per cent)of the beneficiaries had 'farming only' as their main occupation. 55 percent of the beneficiaries lived in joint families whereas 45 per cent lived in nuclear families. 86.67 per cent of the beneficiaries lived in cemented houses and 13.33 


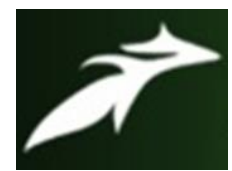

Pilli Rosey Chetana et al, International Journal of Advances in Agricultural Science and Technology,

Vol.7 Issue.12, December-2020, pg. 45-49

ISSN: 2348-1358

Impact Factor: 6.057

NAAS Rating: $\mathbf{3 . 7 7}$

percent lived in semi-cemented houses. 83.34 per cent of the beneficiaries were landless followed by 13.33 per cent whose land is less than 3 acres and 3.33 per cent has land upto 6 acres. 83.34 per cent of beneficiaries earned upto 20,000 within a year, 13.33 per cent earned upto 30,000 and 3.3 per cent earned upto 40,000 within a year.

Table 2: Knowledge of Beneficiaries about MGNREGA

\begin{tabular}{|c|c|c|c|c|}
\hline \multirow[t]{2}{*}{ S. No } & \multirow[t]{2}{*}{ Statements } & \multicolumn{3}{|c|}{ No. of beneficiaries $(N=60)$} \\
\hline & & Fully correct & Partially correct & Incorrect \\
\hline 1. & Full form of MGNREGA & $60(100 \%)$ & $0(0 \%)$ & $0(0 \%)$ \\
\hline 2 & $\begin{array}{l}\text { Days of guaranteed employment } \\
\text { provided under MGNREGA }\end{array}$ & $55(91.67 \%)$ & $5(8.33 \%)$ & $0(0 \%)$ \\
\hline 3 & $\begin{array}{l}\text { Any training or awareness programme } \\
\text { conducted by officials for } \\
\text { MGNREGA? }\end{array}$ & $34(56.67 \%)$ & $26(43.33 \%)$ & $0(0 \%)$ \\
\hline 4 & Do you know about job card? & $54(90 \%)$ & $6(10 \%)$ & $0(0 \%)$ \\
\hline 5 & $\begin{array}{l}\text { Days taken for the job card to be } \\
\text { issued }\end{array}$ & $32(53.33 \%)$ & $28(46.67 \%)$ & $0(0 \%)$ \\
\hline 6 & $\begin{array}{l}\text { How frequently shall social audit be } \\
\text { conducted? }\end{array}$ & $45(75 \%)$ & $15(25 \%)$ & $0(0 \%)$ \\
\hline 7 & $\begin{array}{l}\text { Work is provided within how many } \\
\text { kilometers of radius? }\end{array}$ & $48(80 \%)$ & $12(20 \%)$ & $0(0 \%)$ \\
\hline 8 & Who issues muster roll? & $60(100 \%)$ & $0(0 \%)$ & $0(0 \%)$ \\
\hline 9 & $\begin{array}{l}\text { Mode of payment to MGNREGA } \\
\text { workers }\end{array}$ & $60(100 \%)$ & $0(0 \%)$ & $0(0 \%)$ \\
\hline $\mathbf{1 0}$ & Quota for women under MGNREGA & $34(56.67 \%)$ & $26(43.33 \%)$ & $0(0 \%)$ \\
\hline 11 & $\begin{array}{l}\text { Maximum period taken for wage } \\
\text { payment }\end{array}$ & $31(51.67)$ & $25(41.67 \%)$ & $4(6.67 \%)$ \\
\hline 12 & Benefits under MGNREGA. & $52(86.67)$ & $8(13.33)$ & $0(0 \%)$ \\
\hline
\end{tabular}




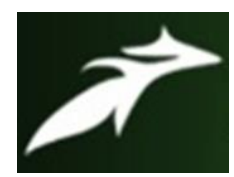

Pilli Rosey Chetana et al, International Journal of Advances in Agricultural Science and Technology, Vol.7 Issue.12, December-2020, pg. 45-49

ISSN: 2348-1358

Impact Factor: 6.057

NAAS Rating: 3.77

Table 3:

\begin{tabular}{|l|l|l|l|}
\hline S. No & Category & Frequency & Percentage (\%) \\
\hline $\mathbf{1 .}$ & Low (25-28) & 3 & 5 \\
\hline 2. & Medium (29-32) & 32 & 53.33 \\
\hline 3. & High (33-36) & 25 & 41.67 \\
\hline TOTAL & $\mathbf{6 0}$ & $\mathbf{1 0 0 \%}$ \\
\hline
\end{tabular}

It is found from table 3 that 53.33 per cent of beneficiaries had medium level of knowledge followed by 41.67 per cent who had high level of knowledge and 5 per cent of the beneficiaries had low level of knowledge about MGNREGA. In order to increase the knowledge of the beneficiaries, necessary awareness programmes should be conducted on timely basis.

\section{CONCLUSION}

It has been concluded from the study that most of the beneficiaries of Bapatla Mandal have medium level of knowledge about MGNREGA. There are few aspects where people are still in lack in gaining complete knowledge about MGNREGA due to poor response of officials in creating awareness among the people time and again.

\section{REFERENCES}

[1]. Argade, S. A. 2010. A study on National Rural Empowerment Guarantee Scheme in Thane district of Maharashtra. M.Sc. (Ag.) Thesis (Unpublished), Acharya N G Ranga Agricultural University, Hyderabad (A. P).

[2]. Das Darshana (2016) "Role of MGNREGA in Rural Employment: A study of Barpeta District of Assam, India”. International Journal of Humanities \& Social Sciences, 2(6): 241248.

[3]. Gajre R.R (2012) "Impact of MGNREGA on Poverty, Agriculture sector, Non- Agriculture sector and Food Inflation". Vario. Multi-Dis. E-Res. J. 2(IV):1-18.

[4]. Kumar V. (2014) "Social Audit in MGNREGA: A case study of three districts of Haryana,". Shiv Shakti International Journal in Multidisciplinary and Academic Research, 2014, Vol. 3(3), pp 171-181.

[5]. K.V.S. Prasad, "Performance of Mahatma Gandhi National Rural Employment Guarantee Act (MGNREGA): An Overview, "International Journal of Management \& Business Studies, 2012, Vol. 2 (4), pp 99-103.

[6]. Pamecha Suman et al., (2015) "Socio-Economic Impact of MGNREGA- A study undertaken among Beneficiaries of 20 villages of Dungarpur District of Rajasthan". International Journal of Scientific and Research Publications, 5(1):1-4. 